\section{Endnu en havfrue}

af John Fellow, redaktor af Carl Nielsen Brevudgaven, Det Kongelige Bibliotek.

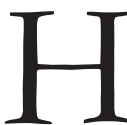
avfruer er ingen sjældenhed, $i$ hvert fald ikke i sjælelivet og $\mathrm{i}$ kunsten. For den danske nation er havfruen i kraft af H.C. Andersens eventyr og den mindre kendte Edvard Eriksens endnu mere kendte lille havfrue ved Langelinie ligefrem blevet nationalt symbol, varemærke og turistmagnet.

Otte år efter at brygger Carl Jacobsen havde ladet Den Lille Havfrue opstille, skabte Anne Marie Carl-Nielsen i 1921 sin Havfrue. Næste forår udstillede hun den på Den Frie Udstilling, og det hed i Social-Demokraten: "Midt i den nye Sal dominerer en stor, grøn Havfrue, som Anne Marie Carl-Nielsen har forsynet med Hale og alt, hvad der hører en Havfrue til." Deraf kan man slutte, at hvad hun udstillede, sikkert var en grønmalet gipsafstøbning. Hvad vi kender i dag, er en hvid original gipsafstøbning på Fyns Kunstmuseum i Odense og en bronzeafstøbning, som Statens Museum for Kunst købte af kunstneren for 4500 kr. efter udstillingen i 1922. Nu har Det Kongelige Bibliotek ved velvillige sponsorers hjælp fået fremstillet en ny bronzeafstøbning til opstilling ved havnekajen foran Den Sorte Diamant.

Om denne havfrues tilblivelse ved vi, som om rigtige havfruer, meget lidt. Den 6.5.1922 meddeler kunstneren kort og godt på et postkort sin mand, med hvem kommunikationen, siden det store sammenbrud $\mathrm{i}$ ægteskabet $\mathrm{i}$ 1914 og de følgende år, har knirket og $\mathrm{i}$ perioder været helt indstillet: "I Går fik jeg Brev at Galleriet har købt min Havfrue." Hans svar fra Göteborg to dage senere er lidt mere udførligt, og viser at der om denne sag også har fundet en mundtlig kommunikation sted mellem ægtefællerne: "Det glæder mig at Du har solgt Havfruen til Galleriet. Saa er der dog Retfærdighed til og det var godt, Du ikke sagde noget ved den anden Ophængning. Tillykke dermed! Det er jo en Hæder for Dig men dog langt mere for Galleriet!"

$1 \begin{aligned} & \text { nne Marie Carl-Nielsen havde } \\ & \text { i foråret } 1908 \text { vundet konkur- } \\ & \text { rencen om opførelsen af }\end{aligned}$ ryttermonumentet over Christian 9. på Christiansborg Ridebane, og denne opgave kom til at styre hendes liv igennem 19 år, indtil rytterstatuen endelig blev afsløret i november 1927. Hvad hun lavede sideløbende med denne, var især bestillingsarbejder som hun økonomisk havde god brug for, da kongemonumentet nok var en ære og en drømmeopgave, men nærmest en økonomisk belastning for hende. Således måtte sokkelrelieffet helt spares væk efter at hun havde brugt mængder af tid og kraft på det, og endda med sin arv havde spekuleret $i$ papirer $i$ håb om selv at kunne finansiere det. Det største bestillingsarbejde der blev til i disse år, var Dronning Dagmar-monumentet på Slotsbanken ved Ribe, men også en lang 


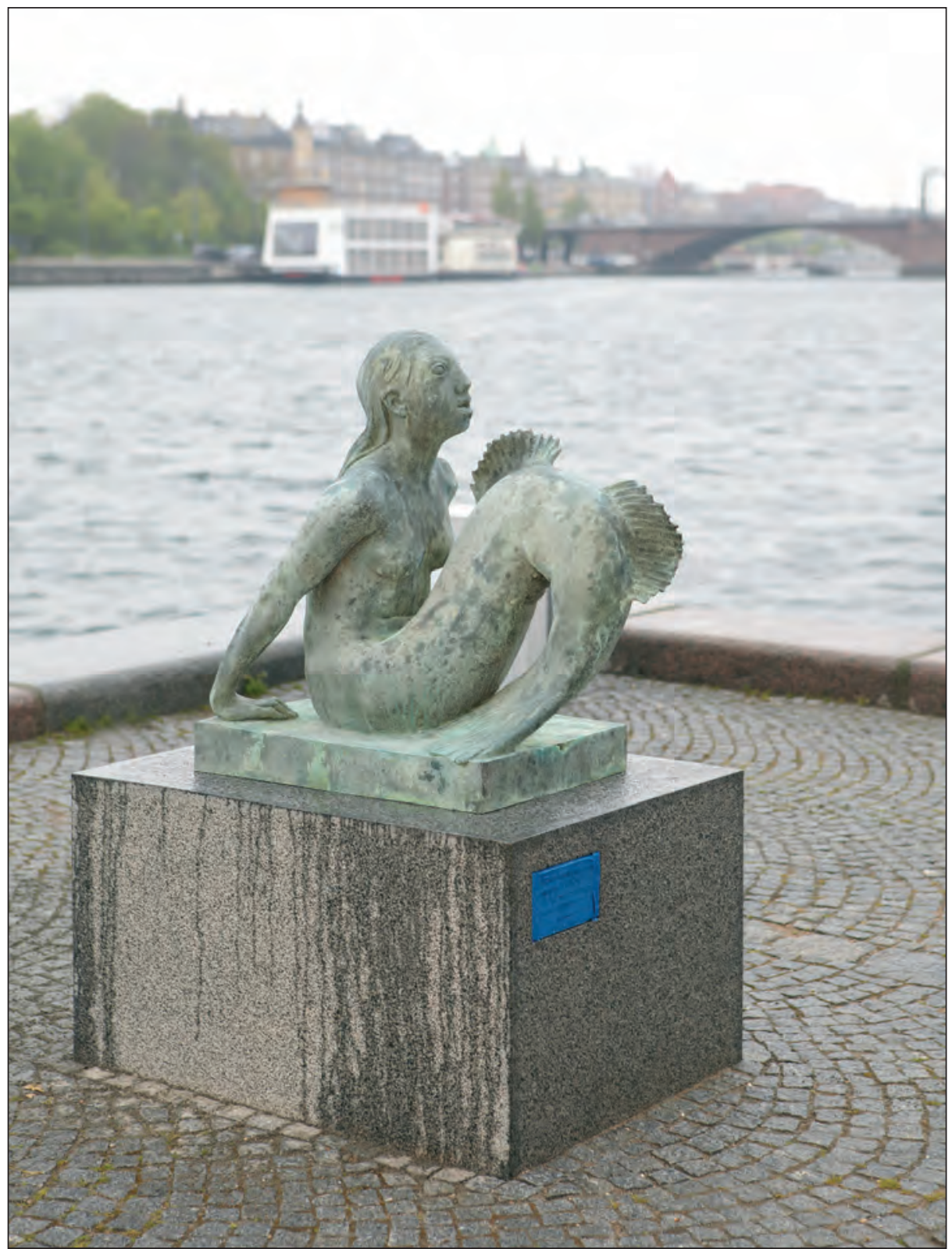

Bronzeleopi 2009. Skeanket af Carl Nielsen og Anne Marie Carl-Nielsens Legat til Det Kongelige Bibliotek. Havfruen er udfort af Bronzestaberiet Leif Jensen ApS, Bagsvard. Fot. Det Kongelige Bibliotek.

række buster og gravmonumenter både i Danmark og i udlandet blev det til.
Som et resultat af ægteskabskrisen var hun fra sommeren $1914 \mathrm{og}$ 
de følgende år i lange perioder lammet i sit arbejde, og hendes Havfrue står som det betydeligste værk, der i denne livsfase blev til uden ydre anledning; måske så meget mere udfra en indre tilskyndelse: en trang til at søge tilbage til det kvindeliges oprindelige tilblivelsestilstand, som det kommer til udtryk i den unge havfrue, der har søgt på land, og som med sit åbne, forvildede blik er spændt ud mellem to verdener, to elementer, havet og landjorden, fuld af vågnende anelser, frygt og håb. Måske har også havfruen været til nogen hjælp i den proces, der førte til at ægteskabet endelig igen kunne klinkes i løbet af året 1922.

Statens Museum for Kunst satte Havfruen op i anlægget foran museet, og der stod hun, indtil hun i foråret 1970 på grund af vejr og vinds angreb blev sat i magasin. Siden har hun kun været udstillet få gange, men er i nyeste tid blevet indlemmet i Museets permanente udstilling. Anne Marie CarlNielsens Havfrue har hverken i virkeligheden eller i vore bevidstheder fået en plads ved siden af Den Lille Havfrue ved Langelinie, og man kan nok undre sig over at det netop var Anne Marie CarlNielsens havfrue med sit stærke, arkaiske udtryk, der skulle forvilde sig så langt bort fra havet.

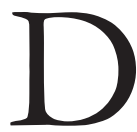
e to havfruer er så forskellige som havfruer kan være, og der er ikke anden grund til at sammenligne, end at det efter opstillingen af Den Lille Havfrue i 1913 er gået sådan at næppe en dansker og heller ikke alverdens turister kan tænke på en havfrue uden at tænke på den lille ved
Langelinie. Det gjaldt allerede Anne Marie Carl-Nielsen, som i kraft af sin mand og hans stilling på Det Kongelige Teater må have haft nært kendskab til omstændighederne omkring Den Lille Havfrues tilblivelse. Det var Julius Lehmanns og Hans Becks ballet Den lille Havfrue, frit efter H.C. Andersen med musik af Fini Henriques, der gav anledning til opstillingen af Den Lille Havfrue; og kunstmæcen og brygger Carl Jacobsens betagelse af ballettens damer, ikke mindst Ellen Price, der dansede titelpartiet i Den lille Havfrue. Og det var Carl Nielsen der som andenkapelmester ved teatret indstuderede musikken til balletten.

Ved premieren den 26.12 . 1909 dirigerede komponisten, Fini Henriques, selv, som han gjorde det ved de første mange forestillinger. Det var komponistens ret dengang, og dirigentrollen var en væsentlig del af indtægten på hans værk. Balletten gik i alt 50 gange i løbet af tre sæsoner, oftest for fuldt hus, og de sidste tyve gange dirigerede Carl Nielsen sin ungdomsvens musik, ligesom han den 1.6.1913 - knap to måneder før Bryggerens monument over balletten blev sat op ved Langelinie - dirigerede Ellen Prices afskedsforestilling, der sluttede med 3. akt af Den lille Havfrue.

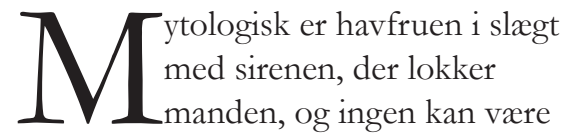
$i$ tvivl om at havfrueverdenen har med en erotisk og seksuel besættelse at gøre som mænd kan stå $i$ fare for at drukne $i$, jævnfør den marmorstøtte af en 


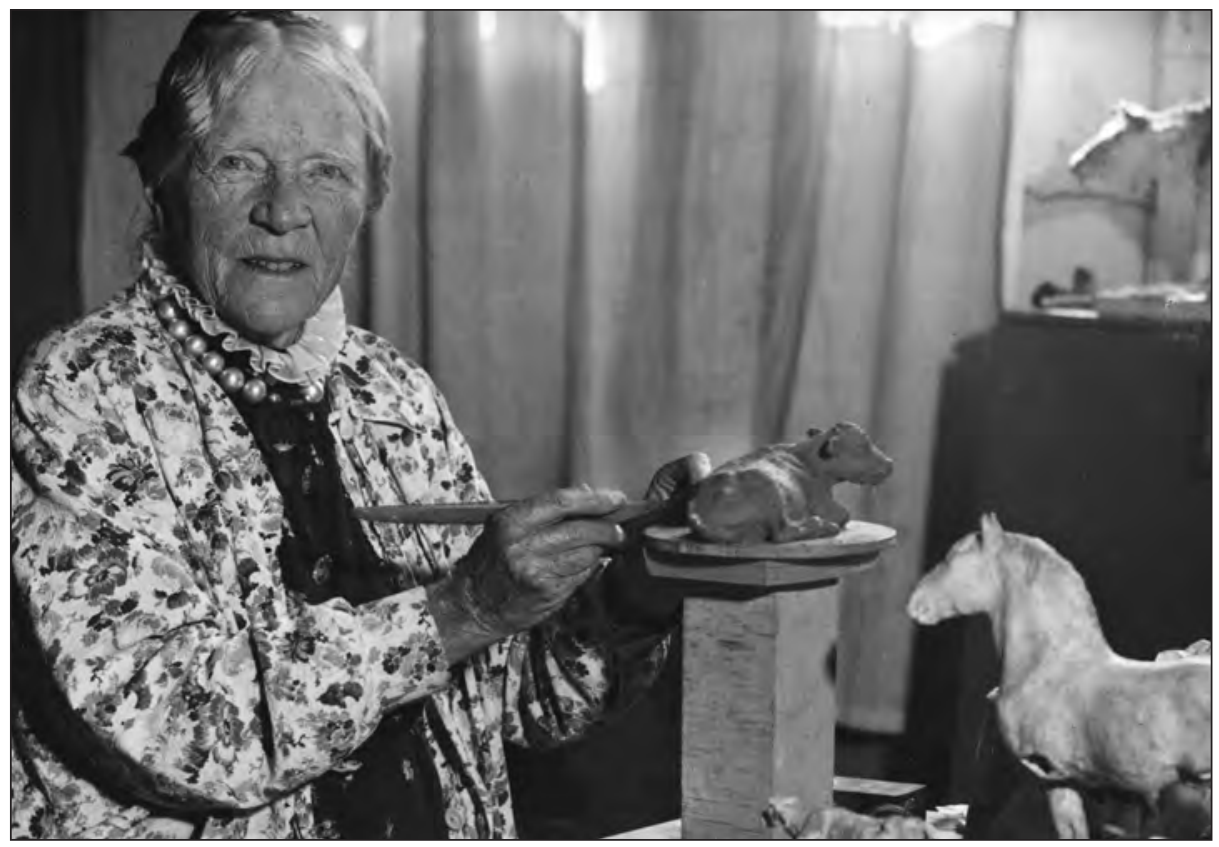

Anne Marie Carl-Nielsen (1863-1945) i sit atelier (Det Kongelige Bibliotek).

dejlig dreng som i Andersens eventyr er havnet i den lille havfrues have på havets bund, og som har tændt hendes længsel efter menneskeverdenen.

Det er H.C. Andersens genistreg, at det er havfruens historie han fortæller, ikke blot historien om mandens besættelse. Det kunne netop han gøre som den utilpassede, evige ungkarl, selv om han på historiens sidste side, efter at prinsen har valgt den forkerte brud, og det kvindeliges forsøg på at stige op og komme til sin ret er endt i forlis, måtte tilføje en opbyggelig morale og lade havfruen, efter at hun er blevet til skum, blive ført til himmels af "Luftens Døtre" med mulighed for om 300 år alligevel at vinde den udødelige sjæl, som var udgangspunktet for hendes længsel og opdrift.
Moralen overtog Det Kongelige Teaters succesfulde havfrueballet fra de glade år før 1. verdenskrig, men ellers forholder ballettens handling sig frit til forlægget hos eventyrdigteren, og prinsens konflikt imellem den nonne af en prinsesse, som hans mor tvinger ham til at gifte sig med, og den dragende havfrue, der som en anden elverpige har meldt sig netop da han står og skal giftes, er i balletten tydeligt en konflikt imellem dyd og erotik, hvori han vælger i overensstemmelse med konventionen, således at hele balletkorpset, efter at havfruen har danset sin Skuffelsens Dans og er faldet besvimet om, kan slå sig løs i den hule Livsglædens Dans, som langt op i 1900-tallet var et musikalsk repertoirenummer i radioens underholdningsprogrammer. 
Det var på balletmaner

havfruens sky, troskyldige og sjælfulde skikkelse og mimik, man heftede sig ved i de fleste samtidige anmeldelser af Ellen Prices udførelse af rollen - og endnu i Dansk kvindebiografisk leksikon! - men lektor i klassisk filologi Ove Jørgensen, endnu en evig ungkarl, skrev efter anmeldelserne en kronik om balletten, hvori havfruens solodans i 2. akt skildres med disse ord:

"De lette, halvt svømmende Bevægelser i de rolige, indledende Takter fortæller om Havfruens Liv i Dybet, og medens det funklende Blik bejler til Prinsen, danser hun med den lydhøreste Hengivelse i den smukke Musik. Overgiven og lystig spiller Fisken i det glitrende Vandspejl. Barnet jubler, fordi det ser sig beundret. Æventyret lever. De spæde Fødder rører næppe ved Jorden. Som Skum fra en Sommerbølge flagrer Havfruen i Solskinnet. Prinsen bjergtages af Dansens Trolddom og sender sit Hof bort. Da bliver Barnet Kvinde. Fruen fra Havet danser for sin Elsker og drager ham med sig i Dansen. Hendes hvirvlende Bevægelse svøber sig om ham som en blaalig Sølvsky af levende Musik. I xggende Dans glider hun fra ham for at hidse hans Jagtglæde. Sansesvimmel og bedøvet staar Kongesønnens purpurviolette Skikkelse og venter hendes jublende Komme som Stranden Bølgens. Men Bølgen gør sig kostbar: Højt hævet paa Taaspidsen sønderdeler Havfruen i sin Dans Tilnærmelsens Rhytme, til Længslerne sejrer og et luftigt Spring kaster hende i Elskerens Arme."

Ove Jørgensen, der var nær ven af familien Nielsen, sendte kronik- ken med en venlig hilsen til kunstnerparret, og det var i øvrigt ham, der holdt forbindelsen ved lige med dem begge i de perioder, hvor kommunikationen mellem mand og kone var helt indstillet.

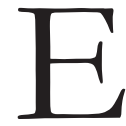
dvard Eriksen forestillede sig Havfruen kastende det bedrøvede blik tilbage mod sine søstre $i$ havet efter at hun var blevet menneske og ikke længere havde fiskehale, og ikke længere havde mulighed for at vende tilbage til sit oprindelige element, mens Bryggeren ikke mente at en havfrue kunne fremstilles uden fiskehale. Det fremgår også af datidens aviser at både Bryggeren og kunstneren havde forestillet sig at Ellen Price skulle sidde model, og i eftertiden har det vedholdende været opfattelsen at det skete. Eriksens søn, Egon Eriksen, der i 1998 udgav en bog om sin far, har imidlertid spurgt Ellen Price mens tid var, og fået svaret: "En kongelig solodanserinde sidder ikke nøgenmodel for en kunstner."

Det gjorde så til gengæld Eriksens kone Eline, ligesom hun var model til Eriksens øvrige kvindeskikkelser. Eline Eriksen var som Ellen Price godt tredive år på dette tidspunkt, men havde modsat hende, der var barnløs, netop født sit tredje barn, sønnen Egon.

Når man ved det, ser man det sagtens i den færdige skulptur, men pudsigt nok ikke længere i den foryngede og "forskønnede" udgave af hans havfrue i de mange bronzeafstøbninger i halv størrelse som senere er solgt til ind- og udland.

Mens balletten både satte et spejl op for tiden og tidstypisk lod den 
danse livsglad hen over det, kom Eriksens lille havfrue til at rumme alle tidens ønskedrømme, uskyld og frugtbarhed i ét: Kvinden, moderen, der længes tilbage mod havets uskyld og måske ubevidst mod de farlige kræfter der gik tabt ved forvandlingen, og som kom med som en svag mindelse i de fiskefinner, som havfruens menneskeben blev forsynet med på Bryggerens opfordring.

Hvad Carl Nielsen, der som dirigent havde balletten mellem sine hænder så mange gange, har ment og følt, ved vi ikke. Men under prøverne før premieren skrev han i Ellen Prices Stambog:

"Kære Fru Price de Plane!

Det er meget vanskeligt at gjøre Rede for sine Indtryk af en Kunstnerpersonlighed; jeg kan det ikke. Men jeg kan i èn Guddommelighed tømme et Overflødighedshorn med Forestillinger, jeg har, naar jeg tænker paa Dem og Deres Kunst:

Maanestraale, Muslingeskal, Amathyst, ungt, duftende Lindetræ, kulørt Lampe, Furesøen, Karlsvognen, Himmelblaat, Pinse, Forlovelse, Søndag, Bøgelund, Studenterhue, Løvspring, Guldsnit, Høduft, Digtsamling, bankende Hjerte, fangen Fugl, sølvglinsende Fisk, Kala, Kilde, Lillie, hvide Duer, Afskedskys, Elfenben med Guldbeslag, Brudelys, Morgendrømme, Himmelstige, Hilsen

Deres hengivne

Carl Nielsen.

6te December 1909. Naar jeg gjennemløber ovenstaaende føler jeg Trang til at bede Dem gaa let hen

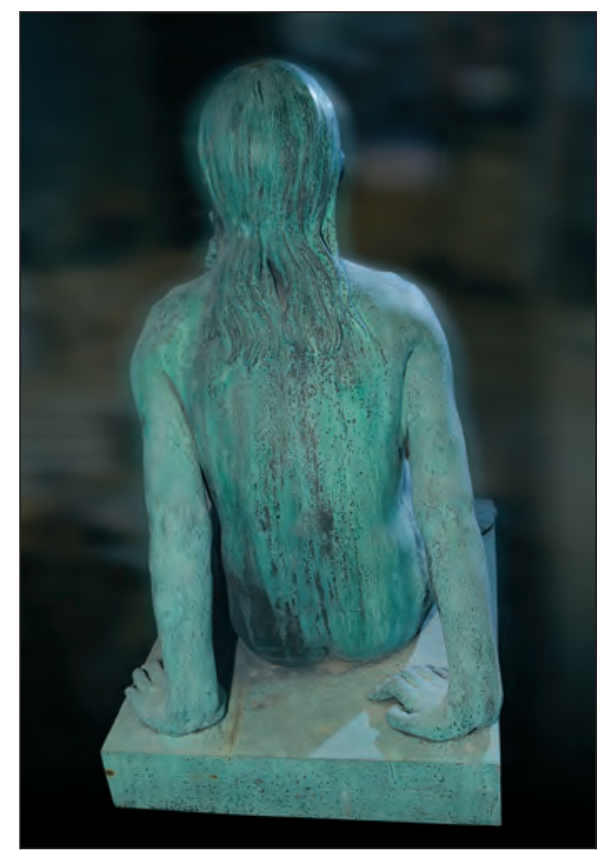

derover. Er der nogen der kan det, maa det være Dem."

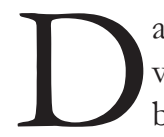
a Carl Nielsens kone efter verdenskrigen og en ægteskabelig og en menneskelig krise af de tungeste skabte sin Havfrue, gik hun ikke let hen over noget. Det var, uafhængigt af andre havfruefremstillinger, den "oprindelige" havfrue hun vendte tilbage til, væsenet der er spændt ud mellem to elementer, fiskenes havdyb og menneskenes jord, psykens urdyb og dens stræben mod menneskelig og guddommelig form. Hun har som H.C. Andersen, hvis havfrue er femten år gammel, da hun første gang stiger op mod menneskeverdenen, skildret sin havfrue i den alder, hvor pigen, mennesket bliver til, med spæde lemmer og ufærdige bryster. Man føler det gærer i 
kroppen, man ser bevidstheden brydes i det førmenneskelige ansigt, munden der gisper efter luft ved mødet med landjorden, de vidt åbne øjne, der er fulde af frygt og forventning ved den fremtid der anes usikkert.

Efter at have været bortgemt $i$ et museumsmagasin $\mathrm{i}$ årtier, sidder Anne Marie Carl-Nielsens havfrue nu med sin store hale på havnekajen ved
Det Kongelige Bibliotek, netop steget op af dybet som på dette sted gennem århundreder har båret navnet Havfruegrunden. Med ansigtet vendt ind mod land, kun et stenkast fra rytterstatuen, behøver hun blot at dreje det en smule til venstre for at øjne huset ovre i Frederiksholms Kanal, hvor hun blev skabt af en kvinde, der bar sin del af havfruekviden. 